\title{
COMPARATIVE INSIGHTS INTO CONSTITUTIONAL HISTORY: CANADA, THE GRITICAL YEARS
}

\author{
Clark R. Cahow*
}

\section{BaCkgRound of Canadian Constitutionalism}

When Her Majesty Queen Elizabeth II presented the Canada Act ${ }^{1}$ to the people of Canada, they alternately hailed the process as the patriation of the existing British North America Act (hereinafter "BNA Act") and the formation of a new Canadian Constitution. Actually it is both, because the Canada Act significantly modifies the BNA Act and very nearly establishes an entirely new constitutional order. The Canada Act will not slow the debate on the efficacy or efficiency of Canadian federalism, nor will concerns for protecting the language and cultural heritage of Quebec be diminished in the minds of the Parti Québécois. The promulgation of the Canada Act, however, with its entrenched Charter of Rights and language guarantee, will significantly alter the terms of the debate about Canadian federalism and its French connection. Now the debate will take place under the aegis of a document which Canadians hope will be a real national constitution, that is, a constitution that embodies the legitimizing First Principle of national sovereignty.

Canadians have had something they call a national constitution since the enactment of the BNA Act by the British Parliament in 1867. By American standards, however, the BNA Act was less than a constitution, because it was not a fundamental charter containing specific provisions that effectively defined the limits of the courts and legislatures with respect to human rights, nor did it embody the essence of national ideals and sovereignty. But to assume that Canada has not had a constitution for the past 115 years misunderstands the Canadian perception of constitutional process, for Canadians place great stock in British notions of constitutionalism.

This misunderstanding has deep historical roots as old as the first conflict between American and British notions of constitutionalism. As historian Bernard Bailyn has noted:

The word "constitution" and the concept behind it was of central importance to the . . minds of both English and Americans, and so great was the pressure placed upon it in the course of a decade of pounding debate [the 1770's] that in the end it was forced apart, along the seam of a basic ambiguity, to form the two contrasting concepts of constitutionalism that have remained characteristic of England and America ever since . . . .

Copyright $\odot 1983$ by LaW and CONTEMPORARy Problems.

* Faculty of Arts and Sciences, Duke University. The author wishes to thank Harold D. Tallant, doctoral candidate in history, for his help in preparing the bibliography and editing this paper.

1. The Canada Act, 1982, ch. 11. 
. : [None of the American] writers who touched on the subject, meant to repudiate the heritage of English common and statutory law. Their claim was only that the source of rights be recognized, in . . . "the laws of nature" . . . but what was the ideal? What precisely were the ideal rights of man? They were, everyone knew, in some sense life, liberty and property. But in what sense? Must they not be specified? Must not the ideal now be reduced from a radiant presence and a conglomerate legal tradition to specific enumerated provisions? Must not the essential rights of man be specified and codified if they were to serve effectively as limits on the actions of courts and legislatures? ${ }^{2}$

Americans answered these questions with notions of constitutionalism that were far different from those of their British predecessors. Canadians, too, have struggled with these questions. Unlike the United States, however, Canada has never resolved them to its satisfaction. Indeed, a central theme of Canadian constitutional history under the BNA Act is the existence of a tension between these two concepts of constitutionalism. Canada has had a written charter which served, in some ways, as an American-style constitution. At the same time, it is clear that British concepts of constitutionalism abound in Canadian thought, and statements to this effect can be found throughout the writings of Canadian constitutional authorities.

Professors R. I. Cheffins and R. N. Tucker contend that the BNA Act "was in no way intended to be a definitive statement of Canada's constitutional functioning. . . . To read the British North America Act [in isolation] would be to get a totally misleading impression of the Constitution." 3 The authors contend that the "document is still the most important one relating to the constitutional process in Canada," 4 but that, "there are other aspects of law within the constitutional framework regulated by conventional practice." 5 . The same position is taken in Professor Frank R. Scott's description of the BNA Act as creating "central and local legislatures which were confined strictly to their prescribed spheres of action by the binding force of the doctrine of Imperial sovereignty. The federal Parliament in Canada cannot invade the provincial sphere, nor the provincial legislature that of Parliament."6 Having established the ground rules for a division of powers, Scott goes on to argue that "convention has long since tempered the rigidity of this fundamental doctrine and the Statute of Westminster of 1931 made some breaches in the actual law." "Convention," he argues, "provides that the unlimited lawmaking power of the United Kingdom Parliament is a ritual or process to be employed at the request of any Dominion for the giving of legal validity to decisions already arrived at in that Dominion. . . . Hence Canada possesses, by convention, a most flexible Constitution."7 Alan C. Cairns adds to the potential confusion in the American mind by arguing that the Canadian Constitution is "in essence not a document but a living institution built . . . around a particular document." It seems apparent that Canadians conceive of "the Constitution" as

\footnotetext{
2. B. Bailyn, The Ideological Origins of the American Revolution 67, $188-89$ (1967).

3. R. Cheffins \& R. Tucker, The Constitutional Process in Canada 7, 10 (1976).

4. Id. at 20 .

5. Id. at 11 .

6. F. Scotr, Essays on the Constitution: aspects of Canadlan Law and Practice 245 (1977).

7. Id.

8. Cairns, The Living Canadian Constitution, 77 QueEN's Q. 483,486 (1970).
} 
something broader than the BNA Act. The key question, then, becomes, how can Canada blend these two notions? How can the nation achieve a constitution of statutory law, common law, and convention within the framework of a written charter?

The tension between these competing ideas has compounded several of Canada's political issues, including those issues connected with federalism. When provincial interests collide with Ottawa or with each other, the issue frequently becomes whether a solution will be found in judicial interpretation or constitutional amendment, or whether it will be found in convention or "extraconstitutional" legislation.

In many ways the new Canada Act speaks to this issue by opting for the American formula. The new Constitution is a document which guarantees citizens rights against government encroachment; changes in governmental structure are to be made by amendment and judicial interpretation; and the Supreme Court of Canada has been given the power to declare legislation unconstitutional, not merely ultra vires. ${ }^{9}$

The incorporation of American-style ideas of constitutionalism into the new Canada Act also speaks to nationality, an issue that is perhaps more fundamental than federal questions. Is the adoption of an American-style constitution necessary for Canada to conceive of itself as a truly independent and Canadian nation? Do independence and full sovereignty mean, almost by definition, the psychological rejection of England's constitutional system? If this is the case, it remains to be seen whether an American-style constitution will provide Canada with the legitimizing First Principle of national sovereignty any more than the BNA Act. It is one thing for the Canada Act to rest on the sovereignty of the Canadian people; it is another for the people to accept the document as the grundnorm or fundamental law. Ultimately, the quest for a Canadian national identity may require Canadians to find a new notion of constitutionalism as Americans found it necessary to replace the Articles of Confederation with a constitution that established a national identity.

\section{AmERican Constitutionalism}

The quest for a constitution expressing national identity and sovereignty has perhaps been easier and more successful in the United States than in Canada. America's success in developing a national spirit is largely rooted in the evolution of American colonial settlements during an age of restless Protestantism which provided Americans with a world view that both promoted settlement and offered a model for developing new American societies. The secularized version of this world view became a large part of the evolving American national identity, and the experience of the American Revolution and the formation of the Constitution in 1787 solidified this fact. While the key ingredients of the emerging American identity were present in the thought of most colonial American Protestants, they are most clearly seen in the thought of the New England Puritans.

9. The Constitution and You 8, 12 (Ottawa 1982). 
As historian Edmund S. Morgan has noted, the Puritans' ideas about politics and government centered around three ideas: the calling, the covenant, and the special relationship between Church and State. ${ }^{10}$ The calling was, perhaps, the most important part of Puritan political thought and was rooted in the Puritans' concept of salvation: that man's total depravity prevented him from effecting his own salvation and only God's selective grace promised salvation to a few "elect" souls. Man, however, could and should strive to be righteous so that he would receive assurance of his own salvation. Those who were not chosen by God for salvation would also benefit from the quest of assurance, for they would place themselves in agreement with God's plan for human society. Each man was "called" by God to fulfill a divinely appointed role. The Puritan idea of the calling could have quite conservative implications when applied to the social realm. As the Puritan governor of the Massachusetts Bay colony, John Winthrop, argued, "God Almightie in his most holy and wise providence hath soe disposed of the Condicion of mankinde, as in all times some must be rich, some poore, some highe and eminent in power and dignitie; others meane and in subieccion." 11 The Puritans believed that just as God called men, he also called nations of men to fulfill his divine appointment, and that just as the Israelites were God's chosen people in Biblical times, so the Puritans were now God's chosen people. Their calling was to separate themselves from the corrupted Christians of the world so that their righteous example would purify these Christians. As Winthrop wrote, "All other churches of Europe are brought to desolation, and it cannot be, but the like judgment is comminge upon us: and who knows, but that God hath provided this place, to be a refuge for manye, whom he means to save out of the general destruction."12. The settlement of Puritans in New England became vested with the idea of a divine calling, a unique mission to become "a city on a hill" which would shine the light and way of salvation to the rest of the world.

If God's chosen people accepted their calling they were placed in a special relationship with God, from which accrued the benefits of His blessing. Just as the Puritans modeled their notion of the calling after the Biblical Israelites, they modeled their notion of their relationship with God after the Israelites' Covenant. The Puritans believed that God would bless and use His chosen nation as long as it fulfilled His calling. So pervasive was the Puritans' notion of the covenant that

10. E. Morgan, Puritan Political Ideas xiii-xlvii (1965). The introduction to Morgan's book is a good, brief synthesis of what has become the standard interpretation of the Puritans' political ideas. For a more detailed discussion of Puritans' thought, see PerRy MILLER, ERRAND InTO The Wilderness (1956). For a recent reappraisal of these ideas, see Bercovitch, New England's Enand Reappraised, in J. Higham \& P. Conkin, New Directions in American Intellectual History 85-104 (1979). Bercovitch writes:

What first attracted me to the study of Puritanism was my astonishment, as a Canadian immigrant, at learning about the prophetic errand of America. Not of America, for the prophecies stopped short at the Canadian and Mexican borders, but of a country that, despite its arbitrary territorial boundaries-despite its bewildering mixture of race and genealogy-could believe in something called America's mission, and could invest that patent fiction with all the emotional, spiritual, and intellectual appeal of a religious quest. Id. at 87 .

11. Winthrop, A Modell of Christian Charity, reprinted in The PurrTans 195 (1938).

12. Quoled in E. Morgan, The Puritan Dilemma: The Story of John Winthrop 40 (1958). 
they believed it extended to include not only man's relationship to God, but also man's relationships with other men. Indeed, when John Winthrop and other Puritan leaders discovered that the charter of the Puritan-dominated Massachusetts Bay Company allowed the company's colony to be governed from the New World, they saw that fact as God's calling to establish a unique form of government made up of righteous men banded together to fulfill God's calling in a colony free from control by the corrupt, old world. The Company's charter itself became a sacred covenant, binding God's chosen people together in a government which would help the people fulfill their calling. As Winthrop stated:

[W] sion, the Lord hath given us leave to drawe our owne Articles . . . if the Lord shall please to heare us, and bring us in peace to the place wee desire, then hath hee ratified this Covenant and sealed our Commission, [and] will expect a strickt performance of the Articles contained in it. ${ }^{13}$

By possession of the Charter, the colonial leaders were able to use it as the cornerstone of the colony's constitution free from interference of England.

According to the Puritans, this sacred government of God's chosen people called forth a special relationship between Church and State. Since the government of God's chosen people was instituted to help them fulfill their calling, and since the Puritans believed that the power of governance was delegated by God, they thought the ultimate role of government was to further God's kingdom. As Puritan teacher and writer John Cotton noted, "It is better that the commonwealth be fashioned to the setting forth of Gods house, which is his Church: than to accommodate the church frame to the civill state." 14 The Puritans, however, did not seek to establish the dominance of the church in governmental affairs. Rather, they hoped that in a commonwealth of God's chosen people, church and state would use different means and powers to achieve the same result, furthering God's kingdom. As John Cotton noted:

[M]agistrates are neyther chosen to office in the church, nor doe governe by directions from the church, but by civill lawes, and . . . by the governors and assistants. In all which, the church (as the church) hath nothing to doe: onely, it prepareth fitt instruments both to rule, and to choose rulers which is no ambition in the church, nor dishonor to the commonwealth

....

. . Purity, preserved in the church, will preserve well ordered liberty in the people, and both of them establish well-ballanced authority in the magistrates. ${ }^{15}$

In the Puritan's view, secular leaders were to further the kingdom of God. Like everything else, the Puritans believed these leaders were called by God to govern the people, as indicated by a vote of the "elect" church members of God's commonwealth. Thus John Winthrop declared:

It is yourselves who have called us to this office, and being called by you, we have our authority from God, in way of an ordinance, . . . the contempt and violation whereof hath been vindicated with examples of divine vengeance... . The covenant between you and us . . . which is to this purpose, that we shall govern you and judge your causes by the rules

13. Winthrop, supra note 11 , at 198.

14. Cotton, Copy of a letter from Mr. Cotton to Lord Say and Seal in the Year 1636, reprinted in The PURrTANS 209 (1938).

15. Id. at $210-212$. 
of God's laws and our own, according to our best skill. ${ }^{16}$

The idea of divine calling of rulers, like the concept of the calling in general, could have very conservative implications. As Winthrop argued in his Journal:

[W] hen the people have chosen men to be their rulers, and to make their laws, and bound themselves by oath to submit therto, now to combine together . . . in a public petition to have any order repealed, which is not repugnant to the law of God, savors of resisting an ordinance of God; for the people, having deputed others, have no power to make or alter laws, but are to be subject. ${ }^{17}$

Yet, this doctrine could also have radical implications, because the Puritans held that it was the duty of God's people to remove a ruler who ignored his calling. Indeed, perhaps the most pressing reason why the Massachusetts Bay colony allowed for frequent elections was to protect God's people from rulers who violated their calling.

Given the basic views outlined above, the leaders of Massachusetts Bay held a tight reign. Nevertheless, in the process of practical governance one hundred new freemen were admitted to the colony in 1631. Each town was established by law in 1635 , as an independent entity with powers to decide all local matters. ${ }^{18}$ The town meeting was granted authority to establish and maintain all laws pertaining to the community, to elect deputies to the legislature, and to elect magistrates. John Cotton preached the 1634 election sermon advocating that magistrates be elected for life. The same year, the freemen repudiated this notion by turning Winthrop out and electing Thomas Dudley as governor. ${ }^{19}$ In 1635 , the secret ballot was instituted upon demand of the freemen. ${ }^{20}$ The Body of Liberteyes were established in 1641 as the first written law code of Massachusetts, and in 1644, upper and lower houses of the legislature were established. ${ }^{21}$ The legislature passed the Township Act in 1647 which granted the franchise to nonfreemen on all local matters, thus extending the influence of the already established town meetings. $^{22}$ This new and wholly secular institution was the vehicle for transferring Puritan religious conviction to political ideology so that by the middle of the eighteenth century "emphasis shifted from the government's obligation to please God to the government's obligation to protect life, liberty and property . . . to please the people."'23

The upshot of the political thought of the Puritans and other American Protestants of the period was the establishment of ideas which became the foundation of the American national ideal. Rulers were to be called to office through the voice of the people and allowed to remain in office only as long as the people believed the rulers were fulfilling that calling. The people and their rulers were to be united together in a special and sacred covenant, an agreement free from outside control,

16. Winthrop, Speech to the General Court, July 3, 1645, reprinted in THE PUR rTANS 205, 206 (1938).

17. Winthrop, Joumal entry for May 22, 1639, reprinted in The PURITANS 202, 203 (1938).

18. R. Wall, Massachusetts Bay: The Crucial Decade, 1640-1650, at 6 (1972).

19. Id. at 9-10.

20. S. Morison, Builders of the Bay Colony 86 (1930).

21. R. Wall, supra note 18, at 17 and 63-64; B. LABAREe, Colonial Massachusetts: A History 74 (1979).

22. R. WALL, supra note 18 , at 228.

23. E. MORGAN, supra note 10 , at xlii. 
in which the people united mutually to pursue their common calling. That calling, or mission, was to institute a righteous and uncorrupted society which would be a light to show the world God's plan for man and, thus, be the instrument of man's salvation. The concept of divine mission, established in the colony, would be a factor in the later acceptance of the American Constitution as a secular article of faith.

Indeed, the evolving world view held by Americans gave them an outlook on public events which made it increasingly difficult for them to remain a part of the British Empire. When Britain began to tighten its governance of the colonies, Americans began to doubt that the British people and government were really the upholders of liberty and republican government. Throughout the crisis which led to the Revolution, Americans began to think of themselves as the only upholders of liberty in a world of corrupt men. Americans saw themselves as a light of liberty, a beacon which would save the empire from corruption. In the early years of the conflict, Americans thought that their example would save the empire from forces which threatened to corrupt it and would touch off an empire-wide reaffirmation of liberty. Separation from the empire came only after the colonists feared that the British people were so hopelessly corrupted that a continued connection with them would destroy the American commonwealth of liberty.

The problem after independence was to establish a government for these apostles of liberty which would secure the mission of these people. The experience of the Revolution taught Americans how easily rulers could violate their calling and abuse the very liberty they were to protect. From this experience Americans wrote their first national constitution, the Articles of Confederation. It established a national government which was intentionally weak.

For all intents and purposes, authority to govern the new nation rested in the states. Americans believed that exercise of power by the states would lessen the danger of tyranny and corruption and thereby preserve republican government. Ultimately, though, the Articles proved to be an insufficient covenant. The Articles were designed to protect liberty from the encroachments of a strong national government. The events of the years after the Revolution, however, convinced many men that the greatest threat to republican government and to a sound exercise of liberty came from the anarchy of competing state interests. Thus, to these men the Articles were responsible for threatening the fruits of the Revolution itself. The solution was to create a new mode of government which received its authority from the sovereignty of the people, not from the state governments. The reformers believed that by establishing a new covenant directly between the people of the nation and the national government, the nation could truly achieve its calling to preserve liberty and republican government. Ultimately, this was to be the success of the American Constitution. It grew out of a concern to protect the national calling, and by institutionalizing the people's image of themselves as a nation, the Constitution quickly became accepted by almost everyone as the embodiment of the national idea.

The new constitution was not, of course, without opponents. Yet, the remarkable fact about the American Constitution is that even its original opponents 
quickly came to view it as an article of national faith. The Antifederalists originally had doubts about the ability of the Constitution to implement the national calling to republican government, because their classical republicanism had trained them to view departures from established republican constitutions as decay, which they saw as the ultimate threat to republicanism. While the Antifederalists were not satisfied that the Constitution was the best possible foundation for the national ideal, their fear of decay encouraged them to uphold the standard of the Constitution against any change. The process encouraged men to transform their doubts about the Constitution into the fear of rulers who seemed to threaten the established republican order. Former Antifederalists became, in the words of historian Lance Banning, "an opposition party which would quickly elevate the Constitution as the palladium of American liberty." 24

In becoming "an opposition that claimed to be more loyal than the government itself," 25 the Antifederalists set the pattern for opposition to governmental policies which has prevailed throughout American history. In this way the American Constitution has become the article of faith of the nation, the vantage point and justification for all actions.

Even in cases where a real governmental crisis called the Union itself into question, Americans found little reason to go outside the Constitution to justify their positions. In the crisis surrounding the passage of the Alien and Sedition Acts in 1798, Thomas Jefferson justified the nullification of federal laws by states by arguing that the Alien and Sedition Acts were "so palpably against the Constitution as to amount to an undisguised declaration, that the compact is not meant to be the measure of the powers of the general government, . . . . [The Alien and Sedition Acts] surrender the form of government we have chosen."26 Later, William Harper of the South Carolina Supreme Court made the same point to justify his state's nullification of the tariffs of 1828 and 1832: "[Congress] hath exceeded its just powers under the Constitution . . . and hath violated the true meaning and intent of the Constitution."27

Such appeals to the Constitution were apparent in the most serious of all American crises, the secession crisis and Civil War. The citizens of Floyd County, Georgia, were just one of many groups of Southerners who voiced constitutional arguments in the midst of the crisis. The North, they declared, had waged "ceaseless war upon their plainest Constitutional rights; . . . an open and shameless nullification of that provision of the constitution intended to secure the rendition of fugitive slaves." 28 The actual secession of the South was not the result of dissatisfaction with the Constitution itself; rather the South left the Union because it felt

24. Banning, Republican Ideology and the Triumph of the Constitution, 31 WM. \& MARY Q. 167, 179 (1974); see also Berens, The Sanctification of American Nationalism, 3 CAN. REV. OF STUD. IN NATIONALISM 172 (1976).

25. Banning, supra note 24 , at 168 .

26. Kentucky Resolutions (Nov. 16, 1798) (Drafted by T. Jefferson), reprinted in H. COMMAGER, DOCUMENTS OF AMERICAN HISTORY 178, 181 (1968).

27. South Carolina Ordinance of Nullification (Nov. 24, 1832) (Drafted by W. Harper), reprinted in $H$. Commager, supra note 26, at 261.

28. Resolutions on Secession from Floyd County, Georgia (1860), reprinted in H. CoMmaGER, supra note 26 , at 362 . 
that the political structure of the nation had placed it in a position of a permanent minority, a political position from which it could not adequately protect its "peculiar" interests. The South, in fact, retained a strong loyalty to the Constitution as an article of faith; even after secession had divided the nation, the South made the Constitution of the Confederate States an almost exact replica of the American Constitution.

In this way the South sought to separate the Constitution and the national ideals it represented from the actual Union of states whose political structure seemed to threaten the interests of the South. In this struggle the South not only employed the text of the American Constitution but also adapted the canon of American heroes and ideals to support its cause. George Washington, Thomas Jefferson, and Andrew Jackson became the forefathers of the Confederacy; the American Revolution became the model for action. Jefferson Davis, the president of the new Confederation, called on Southerners "to perpetuate the principles of our Revolutionary fathers, . . . to maintain our ancient institutions, . . . to renew such sacrifices as our fathers made to the holy cause of constitutional liberty, . . . [and] [t]o show ourselves worthy of the inheritance bequeathed to us by the patriots of the Revolution." 29

The North, too, found reason to call on Washington, Jefferson, and the Constitution to support its cause. For Northerners the question was, will the legacy of the Revolution survive? Will the national calling be fulfilled? "What is now combated is the position that secession is consistent with the Constitution-is lawful and peaceful, . . ." wrote Abraham Lincoln. "On the side of the Union it is a struggle for maintaining in the world that form and substance of government whose leading object is to elevate the condition of men-to lift artificial weights from all shoulders; to clear the paths of laudable pursuit for all; to afford all an unfettered start, and a fair chance in the race of life."30

It should be emphasized that in 1861 the North did not fight the South to wage a war against slavery. They were fighting to preserve the Union. Even Lincoln, though affected by the pall of slavery, thought that "partial and temporary departures"31 from the national ideal might be acceptable, and, indeed, that the preservation of the Union might ultimately require the preservation of slavery. He wrote editor Horace Greeley in 1862 that:

I would save the Union. I would save it the shortest way under the Constitution. The sooner the National authority can be restored, the nearer the Union will be 'the Union as it was.' If there be those who would not save the Union unless they could at the same time save slavery, I do not agree with them. If there be those who would not save the Union unless they could at the same time destroy slavery, I do not agree with them. My paramount object in this struggle is to save the Union, and is not either to save or destroy slavery. If I could save the Union without freeing any slave, I would do it; and if I could save it by

29. Inaugural Address of Jefferson Davis (Feb. 22, 1862), reprinted in H. CoMmaGer, supra note 26, at 407, 408-09.

30. Lincoln's Message to Congress in Special Session (July 4, 1861), reprinted in H. COMMAGER, supra note 26 , at 393,395 .

31. Id. 
freeing all the slaves, I would do it. ${ }^{32}$

By 1863, Lincoln found that the preservation of the Union required the elimination of slavery; and the subsequent course of events cemented the union of what became the North's dual war aims, union and abolition. Beyond the moral effect of freeing four million individuals from slavery, the linkage of union and abolition had profound implications for the future of the American nation. For years before the war slavery was the one continuing irritant on the American political scene. By successfully removing the irritant and at the same time defeating the only successful effort to divide the Union, the American nation seemed to have permanently repudiated secession as a recourse for disgruntled states. Further, by tying the repudiation of secession with the Civil War amendments to the Constitution, the nation seemed to reaffirm its calling and renew its covenant to be a light of liberty to the world. Indeed, some Americans saw the Civil War as God's retribution; the United States, they believed, had betrayed its sacred covenant of liberty and must pay for its violation in blood. God, though, stood ready to forgive His chosen people and renew His covenant with them and bless His nation if they would repent. "Let then no sordid interests or vile prejudices prevent us from a magnanimous, humane and vigorous effort to secure now to four millions of our fellow-men their natural and God-given rights," wrote one American, "then shall war cease, peace and harmony return, and a measure of prosperity such as has never marked the history of our once prosperous but now distracted country." 33 The Civil War became a renewal of the American ideal, an event some have considered the Second American Revolution.

\section{The Development of the Canadian Constitution}

If the growth and development of a national ethos has been a central fact of American history, the comparative lack of a national ethos has been a central theme of Canadian history. The closest parallel in Canada to the strong American sense of national identity has been the nationalism of French-Canadians. It is ironic, though, that the sort of national spirit that became the glue of the American nation is the solvent of the Canadian nation. Though French-Canadian nationalism began in the same period of colonial development as American nationalism, its political and cultural roots differed remarkably from those of American nationalism. While the American variety began as an expression of restless Protestantism, the French-Canadian variety began as an expression of zealous Catholicism. The American ethos tended to be "modern," the French-Canadian ethos tended to be "traditional." While the American spirit was nurtured by representative political institutions, the French-Canadian spirit was nurtured by an authoritarian administrative structure. Yet, both the American and French-Canadian national identities grew out of the process of seventeenth-century colonization. They both represent an adaptation of Old World ideas to the conditions of

32. President Lincoln's Letter to Horace Greeley (Aug. 22, 1862), reprinted in H. Commager, supra note 26 , at $417-18$.

33. J. Fee, Why Agrtate the Slavery Question? (1862). 
the New World, which was encouraged by the colonial political structure. In both cases this adaptation resulted in the growth of an enduring national identity.

For French-Canadians, the process of developing a national ethos began in 1602 , with the grant of a series of monopolies to French fur traders. These monopolies set the stage for a mercantilist industry that became the dominant economic force throughout the entire history of New France. In the same period the church established a foothold through the missionary efforts of the Society of Jesus, which sent the first Jesuit missionaries to New France in 1625. The two groups, one bent on economic gain for France, the other on establishing a Catholic French civilization, supported each other's efforts and were relatively free from crown control until 1663, when Louis XIV established New France as a royal province. Administrative control of public offices passed from the companies to the Crown under the direct authority of a superior council charged with the responsibility of implementing edicts of the king's council in France. Professor Kenneth McNaught points up the administrative arrangement of the council:

Within the superior council of Quebec three figures of power dominated the proceedings: . . . the governor, with primary responsibility for defense and external relations; the intendant, like his counterpart in old France, with special concern for the maintenance of royal power and the administration of justice and economic growth; and the bishop, who wielded considerable authority due to the early groundwork of religious influence laid by the Jesuits. . . . [W] hile it [the council] provided scope for men of outstanding capacity and determination, it failed to develop a body of political representatives with a growing sense of community, such as appeared in the English colonies to the south. Whether one sees in English colonial representative government the beginnings of democracy or simply the advent of Whiggish mixed government, the contrast with New France is nonetheless striking. The tendency of local interests to look to particular men of influence in the government and to think of them as chefs with a natural right to patronage was one that grew steadily in New France. ${ }^{34}$

The administrative structure of the superior council, the influence of the church, the insistence that the raison d'etre of the colony was to provide profit for France under a mercantilist system, and the French legal code that included the seignorial system combined to establish an authoritarian political structure and attitude that, according to McNaught, has not "disappeared in the democracy of present-day French Canada."35 The net result of implicitly uniting the effort to extend the power of Catholic France, the royal goverment, the seignoirs, and the church kept the loyalty of the colonists directed toward a higher authority embodied in the monarchy.

Whether one accepts the view of historians who argue that the defeat of France in the Seven Years' War and the surrender of New France to England were catastrophes that shattered opportunities for self advancement of the French-Canadian society or were merely incidents that "did not cause any profound changes in the fabric of French-Canadian society," 36 the fact remains that the significant elements of the religion, law, and custom of French Canada were preserved with the

34. K. McNaught, The Pelican History of Canada 27 (1973); see also W. Eccles, The CanaDIAN FRONTIER, 1534-1760, at 10 (1969).

35. K. MCNAUGHT, supra note 34, at 28.

36. K. Mackirdy, J. Moir, \& Y. Zoltvany, Ghanging Perspectives in Canadian History: Selected Problems 62 (1971). 
ultimate implementation of the Quebec Act in 1774. While the Quebec Act was passed because of the need for "some imperial apparatus to govern and control the French and Indian frontier incorporated into that empire by the Treaty of Paris," 37 the Act was designed to accomplish more than the establishment of an effective imperial adminstration. The British Parliament was persuaded in its deliberations by the crisis brewing in the American colonies; they hoped that by satisfying French-Canadian hopes for a return to authoritarian local government which would be in the hands of a governor and an appointed council the American rebellion would not spread to Canada.

By speaking to French-Canadian aspirations, however, the Quebec Act precluded any possibility of developing a uniform colonial constitutional structure. Under the Act a dual system of English criminal and French civil law was established in Quebec. The seignorial system of tenure and the authority of the Catholic church were retained. These traditional forms of French-Canadian government were incorporated into the Quebec Act upon the recommendation of Sir Guy Carleton, the governor of Quebec, who "was convinced that the Canadians could best be ruled by a feudal authoritarian system."38

The Quebec Act was promulgated as a matter of administrative convenience, and it was accepted initially as such by most Canadians. Within seventeen years, however, the impact of the American Revolution and the influx into Canada of some 10,000 American Loyalists transformed the colony. The Loyalists wanted to own land without the restrictions of the seignorial system and they wanted legal protection under the British system. Further, the migration of American Loyalists swelled the ranks of the already disgruntled English merchants of Montreal. Although the Quebec Act contained provisions aimed at conciliating these merchants, namely, implementing elements of English commercial law, including "the grant of habeas corpus" and "the use of juries in civil suits," 39 Carleton's refusal to enforce such provisions precipitated several political struggles during the period of the Revolutionary War. By 1790, the hostility of English-Canadians to the Quebec Act made it apparent that "the basic assumptions on which the Quebec Act had been founded now lay in ruin." 40

The British response was, again, an administrative action of convenience. Rather than attempt to alter the Quebec Act to conciliate the English-Canadians at the risk of alienating the French majority, Parliament found at least a temporary solution to the problem by enacting the Constitutional Act of 1791. The colony was divided into the two provinces of Upper and Lower Canada. Lower Canada retained the basic form of government established by the Quebec Act except for the provision that new land grants could be made in freehold at the request of the landowner. Upper Canada was to enjoy the benefits of the English common law and criminal code, and land was to be granted in freehold. A bicameral assembly, with an elective lower house and an appointed upper house, was

37. W. Morton, The Canadian Identity 19 (1972).

38. E. Mcinnis, Canada: A Political and Social History 160 (1969).

39. Id. at 185 .

40. Id. 
established in each province. The provincial government's authoritarian structure was retained by giving the governor the power to veto or reserve bills, and the British Parliament retained the right to disallow all measures. In an effort to provide some equity to the Church of England, Parliament established the right to collect tithes and required the provincial governments to establish land reserves equal to one-seventh of future land grants for support of the clergy. The new government was described by Sir John Graves Simcoe, the governor of Upper Canada, as "the very image and transcript of the English constitution." 41 The obvious intent of the Constitutional Act was to assure a peaceful political cohabitation of the French and English within the colony. In spite of earlier failures to assimilate the French into the British system, some British leaders, notably William Pitt, continued to believe that gradual assimilation would occur. Instead of providing a basis for uniting the colony, however, the Constitutional Act served to generate dissension.

Professor McInnis' summary of what he calls the "vain illusion of unity" best describes the new difficulties that plagued the colonists and the British Parliament.

\footnotetext{
The French found in the new system new opportunities to consolidate their racial and religious separatism. The seeds of racial friction were not eliminated by partition of Canada. The older mercantile groups were left within the bounds of Lower Canada, whose essentially French character was acknowledged by the new measure. The merchants had gained their demand for an assembly, but this was completely stultified by the division of the province, which left the English of Lower Canada in a hopeless minority. Yet their economic and political ambitions were not abandoned; and the result was a steadily increasing friction between the two races in that province and the complete failure of the grant of representative government to solve the problems of Canada. ${ }^{42}$
}

The period from 1791 to 1840 was marked by growing discontent in both Upper and Lower Canada centered on the lack of any connection between the elected assemblies and the appointed governors and councils, the issue of language in Lower Canada, and an animosity, bordering on hostility, between Protestant church groups and the Church of England over the latter's income from one-seventh of all surveyed land. Warnings to the Foreign Office that all was not well went unheeded until brief but open rebellions occurred in both Upper and Lower Canada in 1837. The investigation that followed under Lord Durham's leadership prompted a report calling for uniting the two Canadas into one province in which Francophone Canada East and Anglophone Canada West could share equal representation and abandoning the principle of oligarchy in favor of responsible government.

The British government, however, adopted only a part of the Durham Report; according to Professor Morton, Lord John Russell, the British colonial secretary, "continued the old Whig policy of making over the colonial constitutions."43 The Union Act of 1840 united the two Canadas as Durham had recommended, but it did not grant responsible government to Canada. The British government had again taken an action of administrative convenience that was short-lived. The

41. Id. at 191 .

42. Id. at 192 .

43. W. MORTON, supra note 37 , at 38 . 
movement toward responsible government was not easily quieted; Lord Russell was either unwilling or unable to recognize that a "truly representative system was bound to move flexibly from one area of authority to another."44 Russell's own instructions to the first governor of the united province began the shift toward responsible government; he wrote that the governor, Lord Sydenham, should in most cases choose as ministers men whose "principles and feelings were in accordance with the majority."45 The move toward responsible government continued under Governor Charles Bagot, who installed a ministry led by reformers when they achieved a majority in the assembly. Though this was not a complete acknowledgement of the principle of responsible government since there were still conservatives in the cabinet, Bagot could report by 1841 that "[w]hether the doctrine of responsible government is openly acknowledged, or is only tacitly acquiesced in, virtually it exists." 46 Bagot defended his concession of accepting five reformers into the ministry as the only possible course, and, according to McInnis, "the home government reluctantly accepted his view."47

Responsible government was formally acknowledged in 1847 when the governor, Lord Elgin, asked Louis H. Lafontaine and Robert Baldwin, the leaders of the reformist majority, to form a cabinet. Lord Elgin then set the precedent of not attending cabinet meetings or taking a direct hand in establishing policy. The governor, however, still retained the authority of government set forth in the Union Act.

Professor Morton makes the point that "[i]n achieving self-government, Canadians all unwittingly had set out to be an associated, but equal, nation within the British Empire. No explicit formulation was given to this determination; its revelation was left to the working of time and event." He further points out that "self-government was not a condition but a process. Durham's easy formulation of the subjects to be reserved for Imperial control was . . . easily eroded by the everadvancing claims of the colonies to ever more powers of self-government."48

Matters of local concern rested with the united province, and as McInnis points out, "[ $t]$ he lack of a clear dividing line between imperial and provincial topics resulted in a wide flexibility which allowed the colonies to extend their activities into ever-broadening fields." 49 The hope of achieving harmony between Canada East and Canada West through legislative union was, however, false. Aspects of the political, economic, and religious life of the two provinces became seedbeds of dissension. Representation of the two provinces, one of the most serious points of conflict, was anything but equal when critical issues before the legislature were decided on the principle of the "double majority." The advocacy of representation by population-"rep by pop"-by Upper Canadian radicals threw the French into the position of defending the Union Act. A brief lull in sectional ten-

\footnotetext{
44. K. MCNaUght, supro note 34 , at 97.

45. Id. at 96.

46. E. McINNIS, supra note 38, at 277.

47. Id.

48. W. MORTON, supra note 37 , at 40 .

49. E. MCINNIS, supra note 38, at 299.
} 
sion achieved by Lafontaine and Baldwin and continued into the Morin-McNab ministry allowed the Union to carry forward a relatively effective, if tenuous, existence until the fortunes of the moderates collapsed in the election of 1854. The issues of church land reserves, seignorial tenure, and the location of the provincial capital all served to return sectional differences to the breaking point. Political difficulties threatened the recently secured responsible government with destruction. From 1861 to 1864 , there were two elections and three changes of administration. Political struggles for power within the two provinces spilled over to sectional issues in the assembly to such an extent that by 1864 Canada faced a political and sectional deadlock. ${ }^{50}$

By this time it was apparent that measures would have to be taken to secure the unity of Canada. The solution which Canadian political leaders eventually rallied around was to unify all of British North America into a federal system. The impetus for such a movement came from George Brown, the leader of the Upper Canada reformers and an early advocate of "rep by pop." Brown believed that some form of federation might free Upper Canada from French-Canadian political domination and hoped that French-Canadians might support a new governmental structure which freed them from the constant struggle to preserve their special interests. Likewise, some Confederationists believed that other British North Americans could find reasons to be interested in forming a political union. By uniting the power of all British North America in a strong central government which was given charge of developing the Canadian economy, various provincial aspirations might be served. A governmentally sponsored transcontinental railroad, like that being built in the United States, might secure the prosperity of the Maritime provinces, give Montreal businessmen a chance to compete with their New York rivals, and open the West up for settlement by hemmed-in Upper Canadian farmers. Finally, many Canadian politicians were concerned that the increasing diplomatic troubles between Great Britain and the United States might again spill over into Canada, and with Britain increasingly cool to the defense of its colonies, it seemed to many that Canada's very existence as a political entity required the formation of a government which had the power to defend itself.

Such considerations increasingly influenced Ganadians to support Confederation as a solution to their problems and an expression of their aspirations. The details of the new Confederation were ironed out between May 1864 and March 1867 , and full political acceptance of the idea was hammered out by the efforts of Liberals and Conservatives alike. The result of their efforts, the British North America Act, was enacted by Parliament and went into force on July 1, 1867. It united the four provinces of Nova Scotia, New Brunswick, Ontario, and Quebec into the new Dominion of Canada.

The Confederation addressed many concerns of Canadians of the 1860's. Yet, the act of confederation created new concerns and increased some very old ones. The Fathers of Confederation hoped to address provincial aspirations by creating a strong central government while drawing a sharp line between the interests of

50. Id. at 325 . 
that government and the interests of the provinces. But could such a federal mechanism work? Previous attempts to reform the relationship between the two Canadas had not worked as expected. Now with the introduction of even more diversity by the inclusion of the Maritime provinces in Canada, would the new mechanism work any better? More importantly, if British North Americans created a new nation with Confederation, would the BNA Act so embody the ethos of the new nation that it would serve to bind the nation together despite its diversity?

The new nation would be tested and these questions answered during the next thirty years, a period dominated by the leadership of John A. Macdonald, the Father of the Confederation. This was, indeed, the critical period for the BNA Act, a period when its meaning and the identity of the new nation were to be defined. As one group of Canadians asked, "What is a Canadian? Where is Canada going?"51 Macdonald himself hinted at this problem when he spoke of the need to create a "great nationality-forming a great nation" and "joining these 5 people into 1 . . . to take our position among the nations of the world." 52 Other Canadians echoed this concern. One wrote of "the new nationality that is to be created" and of the problems of creating a Canadian nation when Canadians were "cut into many struggling nationalities." 53 Sir John Rose, the Canadian Finance Minister, spoke of the "vague aspirations of a new nation." 54 Their concern was well founded, because it was doubtful whether Canadians possessed the sort of national spirit which Macdonald hoped would bind the nation together. "It is a fact," wrote the Ottawa Free Press, "that there is not in Canada that national spirit." 55 The Montreal Gazette agreed with this assessment, writing that "this Canadian national spirit is undoubted[ly] the great want . . . of the Canadian people." 56 And, as one modern writer has noted, in the years following Confederation, "[n]ational sentiment was still a distinctly secondary factor . . . and only a few of the leaders betrayed in their speeches evidence of a broad vision of Canadian nationhood . . . [or support for the] nebulous goal of promoting national patriotism." 57

The failure of Canadians to forge a distinctive national ethos in the post-Confederation years can be seen in the two preeminent nationalist movements which arose during the period, the Canada First Movement and Macdonald's Conservative political coalition. The deeply problematic nature of Canadian nationalism can be seen most clearly in the Canada First Movement. "Canada First . . . was a group of nationalists who represented one particular section; . . . it was composed of imperialists who believed in everything from independence to annexation."58 Thus, while Canada First claimed its platform was the only one which truly repre-

51. Quoted in Farrell, The Canada First Movement and Canadian Political Thought, J. OF CAN. STUD., November 1969, at 16, 17.

52. Quoted in id. at 16.

53. Quoted in id.

54. Quoted in id.

55. Quoted in id at 18-19.

56. Quoted in id.

57. Hougham, Canada First: A Minor Party in Microcosm, 19 CaN. J. OF ECON. \& POL. ScI. 174 (1953).

58. Farrell, supra note 51, at 25. 
sented the whole nation, the group was little interested in addressing the concerns of Quebec or the Maritimes; it "looked to the West for Canada's future,"59 but had little notion of the West as anything but an extension of English central Canada. Further, the members of Canada First could never decide what Canada's relationship to the British Empire and the United States should be. They spoke of their desire to see an autonomous Canada within the British Empire, yet they wondered whether that autonomy could be obtained. Some members of Canada First supported a complete break with the empire, an American-style independence. Yet, at this time independence was often a catchword for annexation by the United States, and some members of Canada First seemed to support annexation as the true expression of Canadian nationalism.

Even Macdonald's political coalition was not immune from the problems of Canadian nationalism. From 1867-1873 and again from 1878-1896, Macdonald and his Conservative successors tried to govern in a manner consistent with the principles of nationalism which they thought the BNA Act expressed. The keystone of their policies was the National Policy, a program of national economic development based on protective tariffs and transcontinental railroads. Macdonald also sought and, to a considerable extent achieved, a broadly based national political coalition. If any group should be expected to absorb the national spirit which Macdonald hoped the BNA Act expressed, it should have been his party. But by the late 1890's Macdonald's coalition had foundered on the rocks of provincial interests. The Northwest Territories challenged the Dominion's authority in the Second Riel Rebellion; the Maritimes were near rebellion over federal fiscal policies with Nova Scotia contemplating secession; and Quebec was upset over the government's handling of the Manitoba schools issue.

The failure of Macdonald's coalition to transcend provincial interests in favor of national goals was symbolic of the broader failure of the BNA Act to become the embodiment of any sort of national ideal, the national ethos upon which all actions are justified. In the crucial period following Confederation, Canadians failed to discover exactly what it meant to be a Canadian, and the BNA Act, the founding document of the nation, failed to become the supreme expression of the national ethos.

The lack of a distinctive Canadian identity embodied in a constitution is the root of many of the political problems faced by Canada today. It is significant that today's Canadians felt a need to address these problems by writing a new constitution, for these problems reach beyond the scope of normal political issues to involve the very essence of nationhood. The first of these problems involves the question of the process of amending the Constitution. Until the passage of the Canada Act, the ultimate authority for amending the BNA Act rested with the British Parliament, a fact that concerned Canadians for many years. Although British law and practice allowed Canada to have effective control of the BNA Act, a concern about the symbolism of the arrangement remained. Could Canada

59. Id. at 20 . 
truly be a sovereign and independent nation in her own eyes and in the eyes of the world if her fundamental law could be changed by a British statute?

Professor Frank Scott succinctly spoke about the Canadian concern by posing the question of sovereignty in an address at the 1950 annual meeting of the Royal Society of Canada. "Does it make any difference," he asked, "whether a British statute can extend to Canada whenever the preamble says Canada has requested it, or whether no such statute can have the force of law unless it has been enacted in identical terms by the Canadian Parliament?"60 For Scott, and for Canadians generally, the answer was that there is a great difference:

It is all the difference between the theory that the American constitution rests on the sovereignty of the people- the American people, and the theory that the Canadian constitution rests on the sovereignty of the Parliament-the British Parliament. It is all the difference between having a constitution that is your own and a constitution that belongs to somebody else. . . . We should have no certainty or stability, unless the entire constitution were to become a Canadian constitution, binding on all future Canadian legislatures, and incapable of being altered save by a process which derives its validity from the will of the Canadian people alone. ${ }^{61}$

It is significant that Canada could not assert its nationality by patriating the Constitution because it lacked the depth of national spirit necessary to patriate the Constitution. Provincial concerns for their own well-being always confounded the assertion of a national spirit by preventing the enactment of a Canadian amendatory process. Further, despite the fact that Britain had not exercised its right to legislate for Canada without the permission of the Ottawa government since 1931, many provinces looked to this right as the ultimate guarantee of their interests. With the passage of the new Constitution, Canadians have tried to lay aside these concerns. The question remains, though, whether these concerns will be laid aside in an assertion of national spirit.

Another issue involves what it means to be a Canadian. Do citizens have certain rights which a constitutional government may not violate without trampling upon its own founding principle? Should these rights express the founding principle and extend to all parts of the nation? Should different Canadians have different rights? These questions became increasingly prominent as Canadians watched the explosion of concern for civil liberties in the United States since the 1960's and thought about the significance of civil liberties in their own nation. The traditional Canadian concept of civil liberties revolved around politics. Ultimately, preservation of civil liberties depended on the will of the majority; when rights were infringed, Canadians traditionally sought political rather than judicial remedies. Civil liberties were thought of as the rights of political association: parliamentary democracy, the right to vote, and freedom of speech and press. This conception of civil liberties stemmed from the continuing presence of the Crown in Canadian life. In a fundamental way, civil liberties in Canada represented the people's rights against their sovereign to replace the monarch's unworthy ministers. Increasingly, however, as the Crown's presence in Canada became less pronounced, and effective sovereignty came to rest in the Canadian people, civil

60. F. SCOTT, supra note 6 , at 248.

61. Id. 
liberties came to mean persons' rights against the majority. How then could civil liberties be protected under the BNA Act? Paul C. Weiler described "the nature of the problem" when he stated that:

The major impetus in Canada for a constitutional Bill of Rights is concern for Canadian unity when challenged by cultural dualism. One important reason why Pierre Trudeau has always insisted on a new Bill of Rights has been his commitment to guarantee language rights to all French Canadians and thereby to defuse the threat of Québécois nationalism. ${ }^{62}$

Quebec objected to the constitutionally entrenched Bill of Rights that now supersedes the legislative Bill of Rights which it supported in 1960. In spite of the difficulties which arose out of the objections, Professor Weiler argued that " $[w] e$ should entrench our fundamental rights in the Canadian constitution in order to give them the legal and symbolic authority which could be conducive to their flourishing."63 But what will the new guarantee mean? Will it embody Canadians' concept of themselves? Will this expression of national citizenship be accepted?

The final issue of language and culture involves both civil liberties and the nature of the Union. Previous constitutional settlements attempted to determine to what extent Canada would be a bicultural nation. None of these settlements ever satisfactorily determined the level of Canada's biculturalism nor answered the question of what biculturalism meant to Canadian nationality which helped lead to the failure of each. The BNA Act, for instance, provided for definite but "limited bilingualism and biculturalism,"64 but by the 1890's this settlement was already inadequate. Later attempts to address the inadequacy through the politics of convention were transitory, and the ferment of the Quiet Revolution in Quebec only deepened the problem. Canadians now seem so far apart on the issue of bilingualism and biculturalism that achieving a new constitutional settlement is harder than ever.

Symbolic of the divergent outlooks on the issue is the rift between the two French Canadians who are now the chief protagonists of the language issue, Pierre Elliott Trudeau and René Lévesque. Both men agree that Canada should be a bicultural nation, as probably do most Canadians, but they differ widely about what the nature of such a society should be. Trudeau is interested in building a nation in which each individual's language and culture are respected by society and guaranteed by the government. He argues that "certain fundamental rights and freedoms should, in a democratic society, be reserved to individuals and minorities and be untouchable by the state." 65 Trudeau's position is that language rights of minorities should be protected wherever they may be found, a position which serves to protect English language rights in Quebec. It is at precisely this point that he conflicts with Lévesque. The Quebec premier's primary concern is

62. Weiler, Of Judges and Rights, or Should Canada Have a Constitutional Bill of Rights? 60 DALHOUSIE REV. 205, 207 (1980).

63. Id. at 231 .

64. Forsey, The British North Americe Act and Biculturalism, 71 QUEEN's Q. 141 (1964).

65. Pierre Elliott Trudeau, "Prime Minister's Reply to the Letter Addressed to Him on September 9, 1977, by the Premier of Quebec," in Canada, Office of the Prime Minister, "Prime Minister's Letter to the Premier of Quebec and Position of the Federal Government on Quebec's Bill 101, October 6, 1977," Ottawa, 1977 (typescript). 
the building of a French-Canadian nation. Thus, his concern for minority language rights extends only to the rights of Francophones. He sees Trudeau's desire to protect English minority language rights in Quebec as "a threat to the very survival of the Francophone community through assimilation,"66 and he opposed the entrenchment of such rights in the constitution. The question for Canada as its new constitution enters the critical years is whether men like Trudeau and Lévesque will be able to settle the language issue and make the Canada Act succeed where previous constitutional settlements have failed.

Canadians stand, just as they did in 1867 , at the dawning of a critical period in their history where they can forge a national identity or repeat the failures of the past. The authority that once rested with the British Parliament as the ultimate guarantor of provincial interests now rests with the sovereignty of the Canadian people. The certainty and stability that Professor Scott speaks of must rely on a "process which derives its validity from the will of the Canadian people" 67 and their sense of nationhood. Likewise, the new Canada Act must embody this sense of nationhood before it can be the structure, the grundnorm, through which the nation's problems are solved. For the new process to be a success, it must rest on the national ideal to accommodate sectional differences. Only time will tell if Canadians will find a national ethos in this critical period that will provide the glue of legitimacy for the new Constitution.

66. René Lévesque, Letter to Pierre Elliott Trudeau, September 9, 1977 (typescript); for the views of one academician who supports Lévesque's position, see Beaujot, A Demographic View on Canadian Language Policy, 5 Can. Pub. POL. 16 (1979).

67. F. SCOTT, supra note 6 , at 248 . 